\title{
Potassium Channel Blockers Inhibit the Triggers of Attacks in the Calcium Channel Mouse Mutant tottering
}

\author{
Catherine J. C. Weisz, ${ }^{1}$ Robert S. Raike, ${ }^{1}$ Luis E. Soria-Jasso, ${ }^{1}$ and Ellen J. Hess ${ }^{1,2}$ \\ Departments of ${ }^{1}$ Neurology and ${ }^{2}$ Neuroscience, Johns Hopkins University School of Medicine, Baltimore, Maryland 21287
}

\begin{abstract}
Humans with the disorder episodic ataxia type 2 (EA2) and the tottering mouse mutant exhibit episodic attacks induced by emotional and chemical stress. Both the human and mouse disorders result from mutations in CACNA1A, the gene encoding the $\alpha_{1} 2.1$ subunit of $\mathrm{Ca}_{\mathrm{v}} 2.1$ voltage-gated calcium channels. These mutations predict reduced calcium currents, particularly in cerebellar Purkinje cells, where these channels are most abundant. 4-Aminopyridine (4-AP), a nonselective blocker of $\mathrm{K}_{\mathrm{v}}$ voltage-gated potassium channels, alleviates attacks of ataxia in EA2 patients. To test the specificity of the effect for $\mathrm{K}_{\mathrm{v}}$ channels, aminopyridine analogs were assessed for their ability to ameliorate attacks of dyskinesia in tottering mice. 4-AP and 3,4-diaminopyridine (3,4-DiAP), which have relatively high affinities for $\mathrm{K}_{\mathrm{v}}$ channels, reduced the frequency of restraint- and caffeine-induced attacks. Furthermore, microinjection of 3,4-DiAP into the cerebellum completely blocked attacks in tottering mice. Other aminopyridine analogs reduced attack frequency but, consistent with their lower affinities for $\mathrm{K}_{\mathrm{v}}$ channels, required comparatively higher doses. These results suggest that aminopyridines block tottering mouse attacks via cerebellar $\mathrm{K}_{\mathrm{v}}$ channels. That both stress- and caffeine-induced attacks were blocked by aminopyridines suggests that these triggers act via similar mechanisms. Although 4-AP and 3,4-DiAP were effective in preventing attacks in tottering mice, these compounds did not affect the severity of "breakthrough" attacks that occurred in the presence of a drug. These results suggest that the aminopyridines increase the threshold for attack initiation without mitigating the character of the attack, indicating that attack initiation is mediated by mechanisms that are independent of the neurological phenotype.
\end{abstract}

Key words: aminopyridine; channelopathy; caffeine; stress; cerebellum; tottering mouse; dystonia; potassium; calcium channel

\section{Introduction}

Episodic neurological disorders are characterized by attacks of debilitating symptoms interspersed with periods of relatively normal function. Although the symptoms can be diverse, including migraine headache, epilepsy, paralysis, ataxia, and dyskinesia, there are marked similarities in both the genetic etiology and the factors capable of triggering attacks in episodic disorders. Genetic mapping studies demonstrate that many episodic disorders are associated with ion channel mutations (Ptacek et al., 1991, 1992, 1994; Ophoff et al., 1996). Furthermore, regardless of the class of ion channelopathy or the expressed symptomology, the precipitants of attacks are most commonly psychological, physical, or chemical stressors (Ptacek, 1997; Bhatia et al., 2000), suggesting the existence of a common mechanism for attack initiation that is independent of the neurological phenotype.

Individuals with episodic ataxia type 2 (EA2) and familial hemiplegic migraine (FHM) experience paroxysmal attacks of migraine, ataxia, and other neurological signs that are triggered by emotional stress, exercise, caffeine, or ethanol (Griggs and Nutt, 1995; Gordon, 1998; Battistini et al., 1999; Denier et al.,

Received Jan. 10, 2005; revised March 16, 2005; accepted March 16, 2005

This work was supported by United States Public Health Service Grant NS33592. We thank Angela Yin and Me Yeon Shin for technical assistance.

Correspondence should be addressed to Dr. Ellen J. Hess, Department of Neurology, Johns Hopkins University School of Medicine, 600 North Wolfe Street, Meyer, 6-181, Baltimore, MD 21287. E-mail: ehess@jhmi.edu. D01:10.1523/JNEUROSCI.0098-05.2005

Copyright $\odot 2005$ Society for Neuroscience $\quad$ 0270-6474/05/254141-05\$15.00/0
1999; Jen, 1999; Bhatia et al., 2000; Subramony et al., 2003). EA2 and FHM are both caused by mutations in the CACNA1A gene, which encodes the pore-forming $\alpha_{1} 2.1$ subunit of $\mathrm{Ca}_{\mathrm{v}} 2.1$ (P/Qtype) voltage-gated calcium channels (Ophoff et al., 1996). Functional expression studies of some FHM mutations and all EA2 mutations demonstrate reduced $\mathrm{Ca}_{\mathrm{v}} 2.1$ currents (Guida et al., 2001; Jen et al., 2001; Jouvenceau et al., 2001; Wappl et al., 2002; Cao et al., 2004; Spacey et al., 2004), implicating decreased neuronal excitability in disease pathogenesis. Indeed, 4-aminopyridine (4AP), a nonselective blocker of the $\mathrm{K}_{\mathrm{v}}$ family of voltage-gated potassium channels, increases Purkinje cell excitability (Etzion and Grossman, 2001) and prevents attacks in patients with EA2 (Strupp et al., 2004).

The tottering mouse mutant exhibits the common characteristics of human episodic disorders, whereby attacks of dyskinesia are triggered by clinically relevant precipitants such as stress and caffeine (Fureman et al., 2002). Moreover, the tottering syndrome is also a channelopathy, resulting from a mutation within the gene encoding the $\alpha_{1} 2.1$ subunit of the $\mathrm{Ca}_{\mathrm{v}} 2.1$ calcium channel (Fletcher et al., 1996), the same subunit that bears the mutations for FHM and EA2 in humans. Not surprisingly, this mutation also predicts a reduced $\mathrm{Ca}_{\mathrm{v}} 2.1$ current density (Wakamori et al., 1998). The genotypic and phenotypic similarities shared by EA2 patients and tottering mice suggest these mice can be exploited to understand the pathophysiology underlying human channelopathies. By using the aminopyridines, which are effective in treating EA2 (Strupp et al., 2004), to manipulate tottering mouse attacks, 
we demonstrate that the most widely reported triggers, stress and caffeine, induce attacks through the same or similar mechanisms but that independent mechanisms likely govern the initiation and maintenance of attacks.

\section{Materials and Methods}

Animals. Tottering mice (Cacna1 ${ }^{\text {tg }}$ ) on a C57BL/6J background were bred at the Johns Hopkins University. A group of 36 male and female tottering mice ( $8-40$ weeks of age) was used for each experiment. Attack frequency is comparable across age $(p>0.2)$ and between genders $(p>$ 0.2 ; data not shown). All procedures conformed to the National Institutes of Health Guidelines for the Care and Use of Animals and were approved by the Johns Hopkins University Animal Care and Use Committee.

Drug administration. Drugs were administered subcutaneously at a volume of $10 \mathrm{ml} / \mathrm{kg}$. Aminopyridines were dissolved in $0.9 \%$ saline, and if necessary, the $\mathrm{pH}$ was adjusted to $\mathrm{pH} 7.2-7.6$ with $\mathrm{HCl}$. Caffeine was prepared in $0.9 \%$ saline. Drugs were obtained from Sigma (St. Louis, MO).

Dose-response experiments. The highest doses for each compound were first tested on wild-type mice to assess deleterious side effects such as sedation or seizures. Doses at which these effects were observed were excluded. Tottering mice were transferred from the vivarium to the laboratory at least $3 \mathrm{~h}$ before the start of the experiment. For testing, tottering mice were divided into six groups of six animals each and pseudorandomly assigned to one of five drug doses or a saline vehicle group. Mice were injected with drug or saline, followed $10 \mathrm{~min}$ later by restraint in a $60 \mathrm{cc}$ syringe for $10 \mathrm{~min}$ to induce dyskinesia. After restraint, mice were released into a novel cage for behavioral observation (Campbell and Hess, 1998). Observers were blinded to dose of drug. Each drug was tested on at least two separate dates, and mice were given at least 1 recovery day between experiments. No mouse received the same dose of drug more than once. Doses were balanced for age and sex within the constraints of pseudorandom dose assignment.

Mice were scored for the presence or absence of an attack every $10 \mathrm{~min}$ during the $40 \mathrm{~min}$ immediately after release from restraint as a measure of attack frequency. If an attack occurred within the first $40 \mathrm{~min}$ after release, the duration of attack was determined using the total number of $10 \mathrm{~min}$ intervals for the entire attack up to $120 \mathrm{~min}$, corresponding to the $\sim 2 \mathrm{~h}$ half-life of 4 -aminopyridine in rodents (Capacio et al., 1996). Tottering mice were also observed for $30 \mathrm{~s}$ every $10 \mathrm{~min}$ and assigned a disability score, using the following scale [modified from Jinnah et al. (2000)]: 0 = normal motor behavior; 1 = slightly slowed or abnormal movements; 2 = mild impairment, limited ambulation unless disturbed, transient abnormal postures; 3 = moderate impairment, limited ambulation even when disturbed, frequent abnormal postures; $4=$ severe impairment, almost no ambulation, sustained abnormal postures; $5=$ prolonged immobility in abnormal postures. The median score for each attack was determined and used for statistical analyses.

Caffeine challenge. One-half of the group of 36 was administered aminopyridine, whereas the other half was administered saline vehicle. Thirty minutes after drug or vehicle pretreatment, all mice were injected with 5 or $15 \mathrm{mg} / \mathrm{kg}$ caffeine. Tottering mice were scored as described above. There was at least 1 recovery day between each test day.

Microinjections. For cerebellar microinjections, mice were anesthetized with Avertin, a small incision was made, and a hole was drilled for cannula implantation. A guide cannula (1.5 mm long; Plastics One, Roanoke, VA) was inserted into the midline cerebellum and affixed to the skull using dental cement. The wound was closed with sutures, and mice were allowed to recover for 1 week. Mice were then anesthetized with isoflurane, and the injection needle, which extended $0.5 \mathrm{~mm}$ beyond the guide cannula, was inserted. Mice were injected with $0.5 \mu \mathrm{l}$ of $100 \mu \mathrm{M}$ 3,4-diaminopyridine (3,4-DiAP) or saline vehicle into the midline cerebellum. For lateral ventricle microinjections, mice were anesthetized with isoflurane, and $0.5 \mu \mathrm{l}$ of $100 \mu \mathrm{M} 3,4$-DiAP or saline was delivered into the lateral ventricle (anteroposterior, $-0.5 \mathrm{~mm}$ bregma; lateral, 1.25 $\mathrm{mm}$ ) using a Hamilton syringe with a needle cut to $3 \mathrm{~mm}$. The wound was reapproximated and sealed with Nexaband S/C topical skin closure
(Veterinary Products Laboratories, Phoenix, AZ). To verify injection sites, $1: 5 \mathrm{v} / \mathrm{v}$ of trypan blue (0.4\%; Sigma) was added to the 3,4 -DiAP or saline. All mice were injected with $5 \mathrm{mg} / \mathrm{kg}$ caffeine (subcutaneously) $\sim 2$ min after microinjection. Mice recovered within 5-10 min and were scored for attacks as above.

Statistical analysis. A logistic regression was used to analyze attack frequency data. The duration of attack was analyzed by ANOVA, and severity was analyzed by Mann-Whitney $U$ test or Kruskal-Wallis test, where appropriate.

\section{Results}

\section{Aminopyridines prevent stress-induced attacks}

To determine whether 4-AP blocks attacks in tottering mice, similar to patients with EA2, drug effects were first tested on restraint-induced attacks of dyskinesia. At a dose of $1 \mathrm{mg} / \mathrm{kg}$, 4-AP significantly reduced attacks (Fig. $1 A$ ). Next, two other monoaminopyridine compounds, 2-aminopyridine (2-AP) and 3-aminopyridine (3-AP), were tested for efficacy in similarly reducing the frequency of restraint-induced attacks. Although neither drug completely blocked attacks, both significantly decreased the frequency of attacks at doses $\geq 2.5 \mathrm{mg} / \mathrm{kg}$ (Fig. $1 B, C$ ). Several diaminopyridines were also tested for the ability to block restraint-induced attacks. Interestingly, 3,4-DiAP, which is used in the treatment of the $\mathrm{Ca}_{\mathrm{v}} 2.1$ calcium channel autoimmune disorder Lambert-Eaton myasthenic syndrome, significantly reduced the frequency of attacks at every dose and eliminated them at the 2.5 and $5 \mathrm{mg} / \mathrm{kg}$ doses (Fig. 1D). However, 4-dimethylaminopyridine (4-DMAP) (Fig. 1E) blocked attacks only at $20 \mathrm{mg} / \mathrm{kg}$. 2,6-Diaminopyridine exhibited limited efficacy, and 2,3-diaminopyridine was not at all effective (data not shown).

\section{Aminopyridines block caffeine-induced attacks}

To determine whether aminopyridines could also block caffeineinduced attacks of dyskinesia, tottering mice were treated with aminopyridines before caffeine challenge. Like stress, caffeine is a reliable trigger of attacks in tottering mice (Fureman et al., 2002). Unlike stress levels, the dose of caffeine is easily manipulated to control the frequency of attack. At both 5 and $15 \mathrm{mg} / \mathrm{kg}$ caffeine, $5 \mathrm{mg} / \mathrm{kg}$ 3,4-DiAP, $1 \mathrm{mg} / \mathrm{kg}$ 4-AP, and $20 \mathrm{mg} / \mathrm{kg}$ 4-DMAP significantly reduced the frequency of attacks in tottering mice (Table 1). All other aminopyridines were ineffective against 5 or 15 $\mathrm{mg} / \mathrm{kg}$ caffeine.

\section{Aminopyridines do not modify the character of attacks}

To determine whether the aminopyridines changed the quality of the attack in addition to reducing the quantity of attacks, the duration and severity of attacks were assessed for all drug doses in which attacks were observed. None of the monoaminopyridines or diaminopyridines changed the duration of stress-induced attacks compared with vehicle-treated tottering mice, even at doses that significantly reduced the frequency of attacks (Fig. 1, line graphs). Furthermore, the severity of attacks was remarkably stable, averaging between 3.3 and 3.8, regardless of drug or dose; the 3-4 range represents moderate to somewhat-severe impairment. Although a significant effect was noted for 4-DMAP $(p<0.05$; Kruskal-Wallis test), this was a result of a decrease in severity only at $5 \mathrm{mg} / \mathrm{kg} 4$-DMAP, and these effects were not consistent over the entire dose range. Overall, despite their ability to block attacks, the aminopyridines did not change the phenotype of "breakthrough" attacks.

Stress-induced attacks in tottering mice are relatively mild; in fact, tottering mice often eat and drink during stress-induced attacks (our unpublished observation). It is possible that stress- 
A

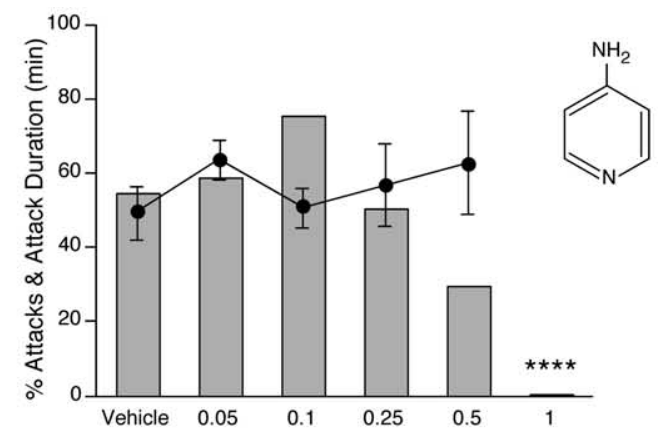

B

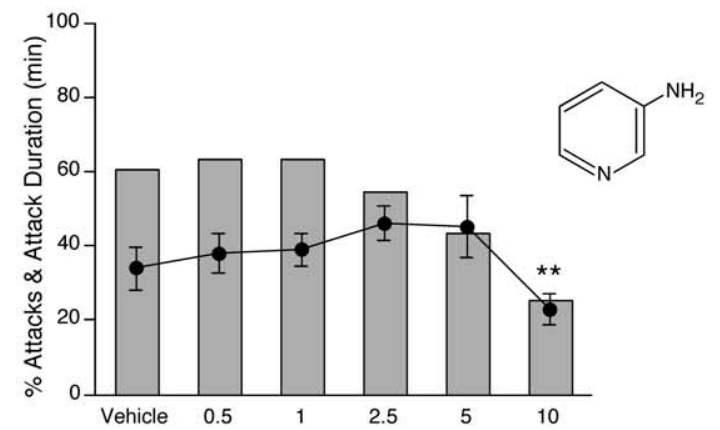

C

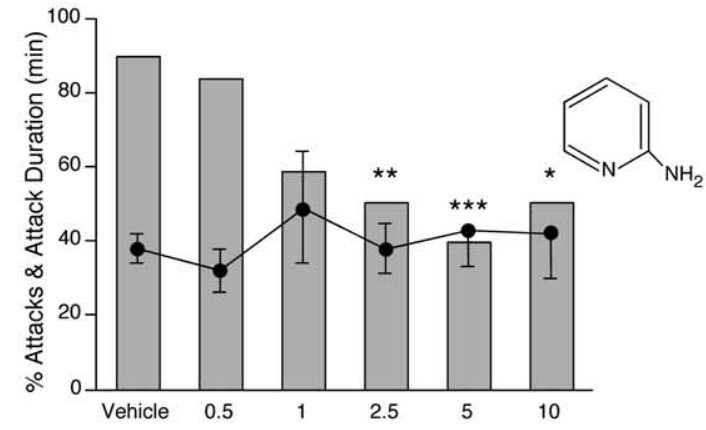

D

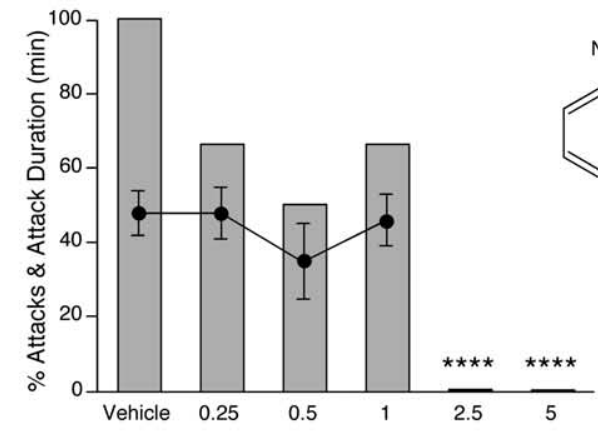

$\mathrm{E}$

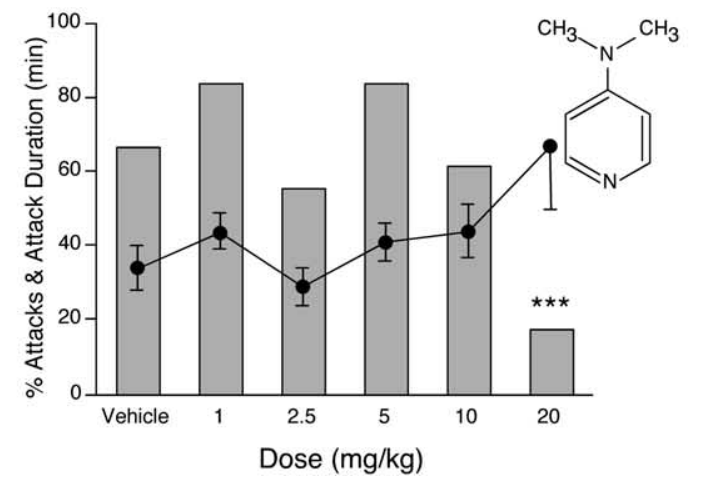

Figure 1. Effect of aminopyridines on restraint-induced tottering mouse attacks. tottering mice were injected with 4-aminopyridine $(\boldsymbol{A} ; n=24$ per dose), 3 -aminopyridine $(\boldsymbol{B} ; n=$ 24-30 per dose), 2-aminopyridine ( $\boldsymbol{C} ; n=24$ per dose), 3,4-diaminopyridine ( $\boldsymbol{D} ; n=12$ per dose), or 4-dimethylaminopyridine ( $\boldsymbol{E} ; n=12-24$ per dose), restrained, and scored for the induced attacks are already at the floor for attacks, whereby severity and duration are relatively insensitive to pharmacological manipulation. Therefore, caffeine was used as a trigger to provide a broader range to expose drug effects. Whereas stress-induced attacks lasted $38 \pm 2 \mathrm{~min}$, caffeine-induced attacks were significantly longer in duration for both $5 \mathrm{mg} / \mathrm{kg}$ caffeine ( $71 \pm 3 \mathrm{~min}$ ) and $15 \mathrm{mg} / \mathrm{kg}$ caffeine ( $92 \pm 3 \mathrm{~min}$; ANOVA, post hoc Scheffé test; $p<0.0001)$. Furthermore, attacks were significantly shorter when induced by 5 rather than $15 \mathrm{mg} / \mathrm{kg}$ caffeine (ANOVA, post hoc Scheffé test; $p<0.0001)$. In contrast to stress-induced attacks, $20 \mathrm{mg} / \mathrm{kg}$ 4-DMAP significantly reduced the duration but not the severity of caffeine-induced attacks. However, despite the efficacy in inhibiting caffeine-induced attacks, neither 3,4-DiAP nor 4-AP significantly reduced the duration or severity of attacks; that is, once initiated, attacks occurred unmodified.

To further test the notion that the sensitivity to the trigger can be modified independent of the attack phenotype, several doses of 3,4-DiAP, the most effective blocker of caffeine-induced attacks, were tested against 5 and $15 \mathrm{mg} / \mathrm{kg}$ caffeine (Table 2). The ability of 3,4-DiAP to inhibit attacks shifted depending on the dose of caffeine and dose of 3,4-DiAP. 3,4-DiAP was clearly more effective against the $5 \mathrm{mg} / \mathrm{kg}$ caffeine challenge than the $15 \mathrm{mg} / \mathrm{kg}$ challenge, significantly inhibiting attacks with 2.5 and $5 \mathrm{mg} / \mathrm{kg}$ 3,4-DiAP. Here again, although 3,4-DiAP dose-dependently reduced the frequency of attacks elicited by both 5 and $15 \mathrm{mg} / \mathrm{kg}$ caffeine, it did not modify either the duration (Table 2) or the severity (data not shown) of the caffeine-induced attack. The reduction in the frequency of attacks essentially without a concomitant reduction in the duration of attacks suggests that the aminopyridines increase the threshold for attack initiation without mitigating attack character.

\section{Aminopyridines act in the cerebellum}

To localize the effect, 3,4-DiAP, which most effectively blocked attacks when administered peripherally, was microinjected into the tottering mouse cerebellum or lateral ventricle. Then, mice were challenged with $5 \mathrm{mg} / \mathrm{kg}$ caffeine to induce attacks. Cerebellar microinjection of $100 \mu \mathrm{M}$ 3,4-DiAP completely blocked caffeine-induced attacks $(n=7)$. In contrast, five of seven mice exhibited attacks after microinjection of saline into the cerebellum. If 3,4-DiAP microinjected into the cerebellum acted by diffusing to other regions, injections into the lateral ventricle should also block attacks. Administration of 3,4-DiAP into the lateral ventricle was ineffective in blocking caffeine-induced attacks, whereby four of five mice exhibited attacks. This attack frequency was comparable with that of saline control mice (five of six), suggesting that the effect of 3,4-DiAP was specific to the cerebellum.

\section{Discussion}

The CACNA1A gene mutations responsible for the EA2 and tottering phenotypes reduce current density from $\mathrm{Ca}_{\mathrm{v}} 2.1$ channels (Wakamori et al., 1998; Guida et al., 2001; Jen et al., 2001; Jouvenceau et al., 2001; Wappl et al., 2002; Spacey et al., 2004), which are expressed abundantly in cerebellar Purkinje and granule cells

presence of an attack. The bar graphs represent the percentage of mice exhibiting attacks; the line graphs represent the average duration of attack. Error bars represent SEM. Attack frequency was analyzed using a logistic regression. All aminopyridines significantly reduced restraintinduced attacks $\left({ }^{*} p<0.05 ;{ }^{* *} p<0.01 ;{ }^{* * *} p<0.001 ;{ }^{* * * *} p<0.0001\right)$. The duration of attack was analyzed by ANOVA and a post hoc Scheffé test; no difference in attack length was observed with any drug, regardless of dose. 
Table 1. Effect of aminopyridines on caffeine-induced attacks

\begin{tabular}{|c|c|c|c|c|c|c|}
\hline \multirow[t]{2}{*}{ Pretreatment } & \multicolumn{3}{|l|}{$5 \mathrm{mg} / \mathrm{kg}$ caffeine } & \multicolumn{3}{|l|}{$15 \mathrm{mg} / \mathrm{kg}$ caffeine } \\
\hline & Percentage of attacks & Duration (min) (mean \pm SEM) & Severity (scale of 1-5) & Percentage of attacks & Duration (min) (mean \pm SEM) & Severity (scale of 1-5) \\
\hline Saline & 81 & $71 \pm 3(68 / 84)$ & $3.4 \pm 0.1$ & 98 & $92 \pm 3(82 / 84)$ & $3.2 \pm 0.1$ \\
\hline 2-AP (5 mg/kg) & 94 & $79 \pm 8(16 / 17)$ & $3.3 \pm 0.1$ & 88 & $86 \pm 8(14 / 16)$ & $3.1 \pm 0.1$ \\
\hline 3-AP (10 mg/kg) & 61 & $65 \pm 11(11 / 18)$ & $3.1 \pm 0.1$ & 94 & $96 \pm 6(17 / 18)$ & $3.2 \pm 0.1$ \\
\hline 4-AP (1 mg/kg) & $40^{* *}$ & $63 \pm 18(6 / 15)$ & $3.3 \pm 0.1$ & $83^{*}$ & $83 \pm 8(15 / 18)$ & $3.1 \pm 0.1$ \\
\hline 3,4-DiAP (5 mg/kg) & $6^{* * * *}$ & $60(1 / 18)$ & 3.0 & $17^{* * * *}$ & $107 \pm 9(3 / 18)$ & $3.5 \pm 0.4$ \\
\hline 4-DMAP (20 mg/kg) & $41^{* *}$ & $29 \pm 9 *(7 / 17)$ & $3.0 \pm 0.1$ & $83^{*}$ & $57 \pm 7^{* *}(15 / 18)$ & $3.1 \pm 0.1$ \\
\hline
\end{tabular}

Values in parentheses represent the number of mice with attacks/the number of mice tested. Each drug was tested concomitantly with a saline pretreatment control group. Asterisks denote significant differences from saline pretreatment as determined by logistic regression for percentage of attacks and ANOVA for duration $\left({ }^{*} p<0.05 ;{ }^{* *} p<0.01 ;{ }^{* * * *} p<0.0001\right)$. Severity data are expressed as means \pm SEM for ease of presentation.

Table 2. Dose effects of 3,4-DiAP on caffeine-induced attacks

\begin{tabular}{llllll}
\hline Pretreatment & \multicolumn{2}{l}{$5 \mathrm{mg} / \mathrm{kg}$ caffeine } & & \multicolumn{2}{l}{$15 \mathrm{mg} / \mathrm{kg}$ caffeine } \\
\cline { 2 - 3 } & $\begin{array}{l}\text { Percentage of } \\
\text { attacks }\end{array}$ & Duration (min) & & $\begin{array}{l}\text { Percentage of } \\
\text { attacks }\end{array}$ & Duration (min) \\
\hline Saline & 84 & $71 \pm 5(36 / 43)$ & 93 & $91 \pm 5(42 / 45)$ \\
$1.0 \mathrm{mg} / \mathrm{kg} 3,4-D i A P$ & 82 & $65 \pm 6(14 / 17)$ & & 100 & $86 \pm 8(16 / 16)$ \\
$2.5 \mathrm{mg} / \mathrm{kg} 3,4-D i A P$ & $47^{* *}$ & $46 \pm 10(8 / 17)$ & & 78 & $77 \pm 7(14 / 18)$ \\
$5.0 \mathrm{mg} / \mathrm{kg} 3,4-D i A P$ & $6^{* * * *}$ & $60(1 / 18)$ & & $16^{* * * *}$ & $107 \pm 9(3 / 18)$ \\
\hline
\end{tabular}

Values in parentheses represent the number of mice with attacks/number of mice tested. Asterisks denote significant differences from saline pretreatment as determined by logistic regression $\left({ }^{* *} p<0.01 ;{ }^{* * *} p<0.0001\right)$ 3,4-DiAP had no effect on duration compared with saline pretreatment. Data for $5 \mathrm{mg} / \mathrm{kg} 3,4-D i A P$ also appear in Table 1. Duration is expressed as mean \pm SEM.

(Stea et al., 1994; Tanaka et al., 1995; Volsen et al., 1995). This may result in a general reduction in Purkinje cell firing rates and loss of inhibition at the deep cerebellar nuclei. Therefore, effective treatments might be expected to offset the mutations by increasing overall Purkinje cell excitability. Based on a preliminary report, 4-AP is one of few compounds that effectively blocks attacks in EA2 patients (Strupp et al., 2004) and is effective in other cerebellar disorders as well (Strupp et al., 2003). Indeed, the therapeutic site of action is likely the cerebellum, because microinjection of 3,4-DiAP into the cerebellum completely blocked attacks in tottering mice. 4-AP and its structural analogs are nonselective blockers of the $\mathrm{K}_{\mathrm{v}}$ family of voltage-gated potassium channels (Coetzee et al., 1999). Several in vitro studies demonstrate that aminopyridines block the intracellular opening of $\mathrm{K}_{\mathrm{v}}$ channels (Peradejordi et al., 1985; Howe and Ritchie, 1991). Blockade of these channels prolongs depolarization by preventing the repolarizing effect of $\mathrm{K}^{+}$efflux. Blocking efficacy depends on the position of the amino group around the pyridine moiety, with 3,4-DiAP and 4-AP having the greatest potency (Molgo et al., 1985; Howe and Ritchie, 1991).

Similar to the reported in vitro pharmacological profiles, the most potent blockers of stress-induced tottering mouse attacks were 3,4-DiAP and 4-AP; both compounds completely eliminated attacks with relatively low doses. In contrast, other aminopyridines, which are weaker bases (Howe and Ritchie, 1991), required higher doses to reduce attack frequency and never entirely blocked attacks. Our in vivo data are similar to in vitro findings in which the rank order of potency for blocking voltagedependent potassium channels was reported as 3,4-DiAP > 4-AP > 3-AP > 2-AP (Molgo et al., 1985). Together, these results suggest that the amino group in the fourth position of the pyridine moiety is important for blocking both channels and attacks. The good correspondence between in vitro and in vivo rank order of potency suggests that the effect of the aminopyridines is specific to $\mathrm{K}_{\mathrm{v}}$ channels and not a result of the spurious action(s) of the compounds at other sites.

Administration of aminopyridines in EA2 patients and tottering mice likely broadens Purkinje cell action potentials as ob- served in vitro. This would increase overall Purkinje cell excitability (Etzion and Grossman, 2001) and thereby restore the inhibitory effects of Purkinje cells on deep cerebellar nuclei. Alternatively, the aminopyridines may be restoring patterns of firing. In acutely prepared slices, dendritic calcium spikes that are generated by $\mathrm{Ca}_{\mathrm{v}} 2.1$ channels terminate burst firing in Purkinje cells (Womack and Khodakhah, 2004). Partial blockade of these channels results in a switch from regular burst firing to tonic firing or irregular bursting (Womack and Khodakhah, 2004). It is likely that the effect of mutant channels in EA2 and tottering is similar to partial pharmacological blockade, whereby inadequate calcium entry fails to terminate burst firing. In fact, in Purkinje cells, 4-AP shortens the duration of the slowly depolarizing potential, which reduces the latency for $\mathrm{Ca}^{2+}$ spikes (Etzion and Grossman, 2001). Thus, blocking $\mathrm{K}_{\mathrm{v}}$ channels with aminopyridines may alleviate attacks by increasing the open time of $\mathrm{Ca}_{\mathrm{v}} 2.1$ channels, allowing appropriate termination of burst firing and producing near-normal patterns of Purkinje cell output to the deep cerebellar nuclei.

Although most aminopyridines tested reduced the frequency of stress-induced attacks in tottering mice, 3,4-DiAP, 4-AP, and 4-DMAP also inhibited caffeine-induced attacks. 3,4-DiAP and 4-AP did not alter the duration of attack, although these drugs were most effective in blocking attacks. This distinction was observed for both stress- and caffeine-induced attacks, suggesting a dissociation between the initiation and maintenance of an attack. Thus, 3,4-DiAP and 4-AP increased the "energy of activation" or threshold for triggering attacks but did not modify the character of attack. The duration of attack was, however, not invariant because caffeine dose-dependently increased duration, whereas 4 -DMAP reduced the duration. This is in sharp contrast to the effects of 3,4-DiAP and 4-AP, which affected frequency but not duration. It is interesting to note that, at high concentrations, 4-DMAP has been reported to block synaptic transmission with a much greater potency than 4-AP or 3,4-DiAP (Matsumoto and Riker, 1984), suggesting that this compound has unique properties that may account for its ability to reduce attack duration. These results suggest that the mechanisms responsible for initiating or triggering the attack are independent of the mechanisms that maintain the attack. Furthermore, that 3,4-DiAP, 4-AP, and 4-DMAP blocked both stress- and caffeine-induced attacks suggests that stress and caffeine trigger attacks through a common pathway that is regulated by neuronal excitability; although it was assumed that the mechanisms were similar, there was previously little evidence to support this notion.

Stress and, to a lesser extent, caffeine are recognized triggers for episodic neurological dysfunction in all channelopathies regardless of the type of ion channel affected or the nature of the attack (Ptacek, 1997; Bhatia et al., 2000). Our results demonstrate that the trigger is independent of the expression of the attack and that different precipitants appear to operate through a common 
path, suggesting that the mechanism(s) underlying the initiation of an attack is similar among triggers and possibly among channelopathies. EA2 patients and tottering mice experience attacks of dyskinesia, which are precipitated by environmental and chemical stressors. In both cases, attacks are associated with mutations that result in a reduction of calcium currents via $\mathrm{Ca}_{\mathrm{v}} 2.1$ voltagegated calcium channels. Along with the neurogenetic similarities, our findings suggest that tottering mice may not only serve as a model of EA2, but also a valuable in vivo and in vitro tool for understanding mechanisms of episodic neurological disease in the context of ion channel dysfunction.

\section{References}

Battistini S, Stenirri S, Piatti M, Gelfi C, Righetti PG, Rocchi R, Giannini F, Battistini N, Guazzi GC, Ferrari M, Carrera P (1999) A new CACNA1A gene mutation in acetazolamide-responsive familial hemiplegic migraine and ataxia. Neurology 53:38-43.

Bhatia KP, Griggs RC, Ptacek LJ (2000) Episodic movement disorders as channelopathies. Mov Disord 15:429-433.

Campbell DB, Hess EJ (1998) Cerebellar circuitry is activated during convulsive episodes in the tottering $(\mathrm{tg} / \mathrm{tg})$ mutant mouse. Neuroscience 85:773-783.

Cao YQ, Piedras-Renteria ES, Smith GB, Chen G, Harata NC, Tsien RW (2004) Presynaptic $\mathrm{Ca}^{2+}$ channels compete for channel type-preferring slots in altered neurotransmission arising from $\mathrm{Ca}^{2+}$ channelopathy. Neuron 43:387-400.

Capacio BR, Byers CE, Matthews RL, Chang FC (1996) A method for determining 4-aminopyridine in plasma: pharmacokinetics in anaesthetized guinea pigs after intravenous administration. Biomed Chromatogr 10:111-116.

Coetzee WA, Amarillo Y, Chiu J, Chow A, Lau D, McCormack T, Moreno H, Nadal MS, Ozaita A, Pountney D, Saganich M, Vega-Saenz de Miera E, Rudy B (1999) Molecular diversity of $\mathrm{K}^{+}$channels. Ann NY Acad Sci 868:233-285.

Denier C, Ducros A, Vahedi K, Joutel A, Thierry P, Ritz A, Castelnovo G, Deonna T, Gerard P, Devoize JL, Gayou A, Perrouty B, Soisson T, Autret A, Warter JM, Vighetto A, Van Bogaert P, Alamowitch S, Roullet E, Tournier-Lasserve E (1999) High prevalence of CACNA1A truncations and broader clinical spectrum in episodic ataxia type 2. Neurology 52:1816-1821.

Etzion Y, Grossman Y (2001) Highly 4-aminopyridine sensitive delayed rectifier current modulates the excitability of guinea pig cerebellar Purkinje cells. Exp Brain Res 139:419-425.

Fletcher CF, Lutz CM, O’Sullivan TN, Shaughnessy JD, Hawkes R, Frankel WN, Copeland NG, Jenkins NA (1996) Absence epilepsy in tottering mutant mice is associated with calcium channel defects. Cell 87:607-617.

Fureman BE, Jinnah HA, Hess EJ (2002) Triggers of paroxysmal dyskinesia in the calcium channel mouse mutant tottering. Pharmacol Biochem Behav 73:631-637.

Gordon N (1998) Episodic ataxia and channelopathies. Brain Dev 20:9-13.

Griggs RC, Nutt JG (1995) Episodic ataxias as channelopathies. Ann Neurol $37: 285-287$

Guida S, Trettel F, Pagnutti S, Mantuano E, Tottene A, Veneziano L, Fellin T, Spadaro M, Stauderman K, Williams M, Volsen S, Ophoff R, Frants R, Jodice C, Frontali M, Pietrobon D (2001) Complete loss of P/Q calcium channel activity caused by a CACNA1A missense mutation carried by patients with episodic ataxia type 2. Am J Hum Genet 68:759-764.

Howe JR, Ritchie JM (1991) On the active form of 4-aminopyridine: block of $\mathrm{K}^{+}$currents in rabbit Schwann cells. J Physiol (Lond) 433:183-205.

Jen J (1999) Calcium channelopathies in the central nervous system. Curr Opin Neurobiol 9:274-280.

Jen J, Wan J, Graves M, Yu H, Mock AF, Coulin CJ, Kim G, Yue Q, Papazian DM, Baloh RW (2001) Loss-of-function EA2 mutations are associated with impaired neuromuscular transmission. Neurology 57:1843-1848.

Jinnah HA, Sepkuty JP, Ho T, Yitta S, Drew T, Rothstein JD, Hess EJ (2000) Calcium channel agonists and dystonia in the mouse. Mov Disord 15:542-551.
Jouvenceau A, Eunson LH, Spauschus A, Ramesh V, Zuberi SM, Kullmann DM, Hanna MG (2001) Human epilepsy associated with dysfunction of the brain P/Q-type calcium channel. Lancet 358:801-807.

Matsumoto M, Riker WK (1984) Effects of several aminopyridines and analogs on the calcium dependence of synaptic transmission. J Pharmacol Exp Ther 228:573-578.

Molgo J, Lemeignan M, Lechat P, Peradejordi F (1985) Increase in evoked transmitter release from motor nerve terminals by some amino $\mathrm{N}$-heterocyclic compounds I. Comparative experimental activities and extracellular pH-dependence. Eur J Med Chem 20:149-153.

Ophoff RA, Terwindt GM, Vergouwe MN, van Eijk R, Oefner PJ, Hoffman SM, Lamerdin JE, Mohrenweiser HW, Bulman DE, Ferrari M, Haan J, Lindhout D, van Ommen GJ, Hofker MH, Ferrari MD, Frants RR (1996) Familial hemiplegic migraine and episodic ataxia type- 2 are caused by mutations in the $\mathrm{Ca}^{2+}$ channel gene CACNL1A4. Cell 87:543-652.

Peradejordi F, Molgo J, Lemeignan M (1985) Increase in evoked transmitter release from motor nerve terminals by some amino N-heterocyclic compounds II. Comparative study on electronic structural properties and reactivity characteristics of neutral and protonated molecular species. The interaction pharmacophore. Eur J Med Chem 20:155-161.

Ptacek LJ (1997) Channelopathies: ion channel disorders of muscle as a paradigm for paroxysmal disorders of the nervous system. Neuromuscul Disord 7:250-255.

Ptacek LJ, George ALJ, Griggs RC, Tawil R, Kallen RG, Barchi RL, Robertson M, Leppert MF (1991) Identification of a mutation in the gene causing hyperkalemic periodic paralysis. Cell 67:1021-1027.

Ptacek LJ, George ALJ, Barchi RL, Griggs RC, Riggs JE, Robertson M, Leppert MF (1992) Mutations in an S4 segment of the adult skeletal muscle sodium channel cause paramyotonia congenita. Neuron 8:891-897.

Ptacek LJ, Tawil R, Griggs RC, Engel AG, Layzer RB, Kwiecinski H, McManis PG, Santiago L, Moore M, Fouad G, Bradley P, Leppert MF (1994) Dihydropyridine receptor mutations cause hypokalemic periodic paralysis. Cell 77:863-868.

Spacey SD, Hildebrand ME, Materek LA, Bird TD, Snutch TP (2004) Functional implications of a novel EA2 mutation in the P/Q-type calcium channel. Ann Neurol 56:213-220.

Stea A, Tomlinson WJ, Soong TW, Bourinet E, Dubel SJ, Vincent SR, Snutch TP (1994) Localization and functional properties of a rat brain $\alpha 1 \mathrm{~A}$ calcium channel reflect similarities to neuronal Q- and P-type channels. Proc Natl Acad Sci USA 91:10576-10580.

Strupp M, Schuler O, Krafczyk S, Jahn K, Schautzer F, Buttner U, Brandt T (2003) Treatment of downbeat nystagmus with 3,4-diaminopyridine: a placebo-controlled study. Neurology 61:165-170.

Strupp M, Kalla R, Dichgans M, Freilinger T, Glasauer S, Brandt T (2004) Treatment of episodic ataxia type 2 with the potassium channel blocker 4-aminopyridine. Neurology 62:1623-1625.

Subramony SH, Schott K, Raike RS, Callahan J, Langford LR, Christova PS, Anderson JH, Gomez CM (2003) Novel CACNA1A mutation causes febrile episodic ataxia with interictal cerebellar deficits. Ann Neurol 54:725-731.

Tanaka O, Sakagami J, Kondo H (1995) Localization of mRNAs of voltagedependent $\mathrm{Ca}^{2+}$-channels: four subtypes of $\alpha 1$ and $\beta$-subunits in developing and mature rat brain. Brain Res Mol Brain Res 30:1-16.

Volsen SG, Day FC, McCormack AL, Smith W, Craig PJ, Beattie R, Ince PG, Shaw PJ, Ellis SB, Gillespie A, Harpold MM, Lodge D (1995) The expression of neuronal voltage-dependent calcium channels in human cerebellum. Brain Res Mol Brain Res 34:271-282.

Wakamori M, Yamazaki K, Matsunodaira H (1998) Single tottering mutations responsible for the neuropathic phenotype of the P-type calcium channel. J Biol Chem 52:34857-34867.

Wappl E, Koschak A, Poteser M, Sinnegger MJ, Walter D, Eberhart A, Groschner K, Glossmann H, Kraus RL, Grabner M, Striessnig J (2002) Functional consequences of $\mathrm{P} / \mathrm{Q}$-type $\mathrm{Ca}^{2+}$ channel $\mathrm{Ca}_{\mathrm{v}} 2.1$ missense mutations associated with episodic ataxia type 2 and progressive ataxia. J Biol Chem 277:6960-6966.

Womack MD, Khodakhah K (2004) Dendritic control of spontaneous bursting in cerebellar Purkinje cells. J Neurosci 24:3511-3521. 